\title{
Effects of chickpea husk on the baking properties of chapattis
}

\author{
A. K. M. S. Inam, M. A. Haque, M. Shams-Ud-Din and M. Easdani \\ Department of Food Technology \& Rural Industries, Bangladesh Agricultural University, Mymensingh-2202, \\ Bangladesh
}

\begin{abstract}
Chickpea husks were extracted by non-alkaline aqueous extraction process and then ground in flour mill. The unextracted husks were also ground in flour mill. The analysis of chickpea husk showed that extracted husk was lower in moisture, protein, ash and fat but higher in carbohydrate and crude fiber contents compared to unextracted husk. Chapattis were prepared incorporating different levels of extracted and unextracted chickpea husk and evaluated for various quality parameters as weight, width, thickness, spread ratio, and moisture content. The chapatti containing extracted husk had higher moisture, carbohydrate and crude fiber content but lower in protein and ash content than that of chapatti containing unextracted husk. Chapattis were also prepared incorporating various levels of salt, baking powder and water. The quality of chapattis was evaluated. Chapatti prepared from $5 \%$ extracted husk required $2.0 \%$ salt, $1.5 \%$ baking powder and $62 \%$ water for producing reasonably acceptable quality while chapatti from $5 \%$ unextracted husk required $1.5 \%$ salt, 1.5\% baking powder and $60 \%$ water for achieving better quality. Chapattis were prepared with $5 \%$ extracted husk required higher salt and water than that of $5 \%$ unextracted husk. Chapattis were evaluated organoleptically by a taste testing panel. The overall acceptability of chapattis without husk was followed by chapattis incorporated with $5 \%$ extracted husk.
\end{abstract}

Keywords: Chickpea, Extracted husk, Unextracted husk, Baking, Chapatti

\section{Introduction}

Legume seeds are second only to cereals as a source of human food and animal feed. Nutritionally they are two to three times richer in protein than cereal grains. Most legume proteins are deficient in methionine. However, these proteins usually contain more than adequate levels of some of the nutritionally important amino acids which are deficient in most cereals. The combination of cereals and legumes provides a good balance of amino acids since cereals supply adequate methionine (Chavan et al., 1978). The estimated total production of legume in Bangladesh is about 3,32,890 tons occupying $10,39,705$ acres of land (BBS, 2007).

In recent years, the uses of legume husks gain importance as the ingredients in the formulation of various food products. Moreover, the legume husk is potentially low cost and is largely available throughout the country. A recent study (Shams-Ud-Din et al., 2006) showed that the processed pea husk could be conveniently utilized in formulations of breads. The dietary fiber enriched with extracted legume husk may be added to foods in a appealing manner to ensure consumer acceptance. The legume husks are rich in dietary fiber (80-93\%) and calcium (32-50\%), where the dietary fiber consists of about $27-47 \%$ crude fiber and $47-60 \%$ Nitrogen-free carbohydrate (Singh et al., 1982).

The dietary fiber includes various components such as cellulose, hemicellulose, lignins, gums, pectic substances, mucilages etc. However, legume husk contains polyphenols, which is considered as antinutritional factor for certain proteins and enzymes (Salunkhe et al., 1985). The role of dietary fiber in human nutrition has recently been increasing interest since it plays a significant role in preventing of certain disease such as constipation, diverticulitis, colon cancer, hemorrhoids, appendicitis, gallstone, hernia, varicose vein, diabetes, coronary heart disease and dental carries (Burkit and Trowell, 1975; Southgate and Penson, 1985; Spiller et al., 1978; Burkit, 1980).

Considering the high content of edible dietary fiber and its importance, chickpea husk was collected and used for the preparation of chapattis, a widely used breakfast food, to study its baking properties.

\section{Materials and Methods}

The experiment was conducted in the laboratory of the Department of Food Technology and Rural Industry under the Faculty of Agricultural Engineering and Technology, Bangladesh Agricultural University, Mymensingh, Bangladesh. 


\section{Preparation of aqueous extracted chickpea husk}

The method of Roberts et al. (1985) was used to prepare extracted chickpea husk. The chickpea husks were suspended in 10 volumes of tap water $(\mathrm{pH} 6.7)$ in a flask and agitated at high speed on a horizontal flask shaker for $16 \mathrm{hr}$ at room temperature $\left(25-30^{\circ} \mathrm{C}\right)$. The resulting suspension was separated from extracted residual husk through cloth. The residual husk was washed five times with water and was designated as extracted husk.

The extracted husk was then dried in a cabinet drier on stainless steel trays for $4-5 \mathrm{hr}$ at $90^{\circ} \mathrm{C}$. After cooling to room temperature, the dried extracted husk were thoroughly mixed and packed in double layered polyethylene bags.

\section{Formulation of chapatti}

The basic formulation used for preparation of chapatti is outlined in Table 1. Various levels of replacement of wheat flour were made with various levels of extracted or unextracted chickpea husk in the formulations of chapatti. This is showed in Table 2.

Table 1. Basic formulation of 10 chapattis

\begin{tabular}{|l|c|}
\hline Ingredients & Quantity \\
\hline Wheat flour & $100 \mathrm{~g}$ \\
\hline Salt & $2.0 \mathrm{~g}$ \\
\hline Baking powder & $1.0 \mathrm{~g}$ \\
\hline Water & $60 \mathrm{ml}$ \\
\hline
\end{tabular}

Table 2. Extracted and unextracted ground chickpea husk used in the preparation of chapatti

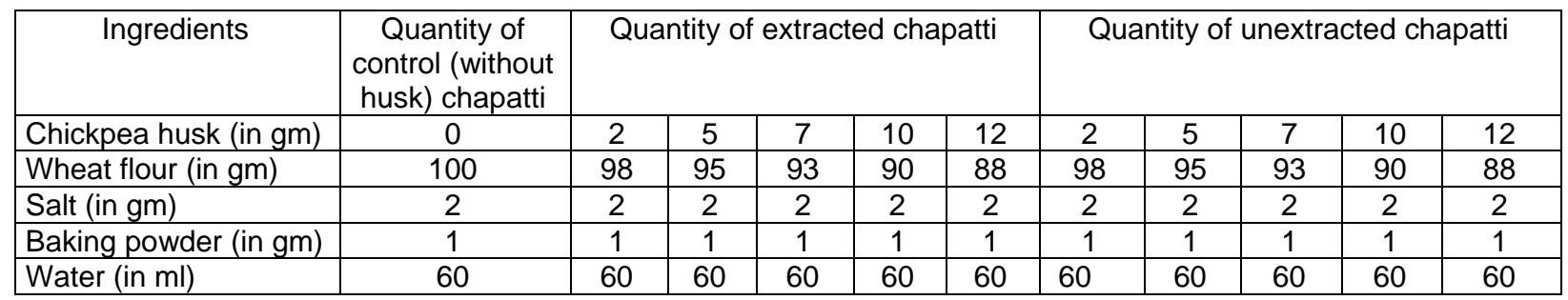

The flour and extracted or unextracted chickpea husk along with other ingredients for the preparation of chapatti were weighed accurately. The ingredients were mixed well for 1 minute and then added the measured quantity of water to make a dough and retained for 15 minutes. The dough was then kneaded and rolled to a uniform thickness of $0.250 \mathrm{~cm}$. To achieve uniform diameters of each chapatti, the rolled sheet was cut out with a round chapatti cutter of $10.3 \mathrm{~cm}$ diameter. Chapattis were baked on preheated non-sticky frying pan for 10 minutes.

\section{Physico-chemical analysis of chapattis}

The chapattis containing 5.0\% extracted and unextracted chickpea husks were analyzed for moisture content, protein, ash and crude fiber as per methods of AOAC (2000). Carbohydrate content of chapatti was determined by subtracting the summation of all ingredients determined above from 100. All the determinations were done in triplicate and the results were expressed as the average value of three.

The spread ratio of chapatti was initially used as an important parameter of chapatti quality. The spread ratio was determined by the formula W/T, where $\mathrm{W}$ is the average diameter (in $\mathrm{cm}$ ) of chapatti and $\mathrm{T}$ is average thickness (in $\mathrm{cm}$ ). The moisture content of the chapattis was determined as per methods of AOAC (2000). Weight (g) of each type of chapattis was also determined. 


\section{Sensory evaluation}

A sensory evaluation of control chapatti and chapattis containing 5\% extracted and unextracted chickpea husk were evaluated for color, flavor, texture and overall acceptability by a panel of 16 testers. The testers were selected among the teacher, officers and MS students of the Department of Food Technology and Rural Industries and were briefed before evaluation. In this case, 9-point hedonic rating test was performed to asses the degree of acceptability of these chapattis. Three pieces from each lot of chapatti lot was presented to each of 16 panelists to rate sample's attribute in ascending order of their choice or preference by giving with numerical number between 1-9 for color, flavor, texture and overall acceptability where the numerical number indicated: $9=$ Like extremely, $8=$ Like verb much, $7=$ Like moderately, 6 = Like slightly, 5 = Neither like nor dislike, 4 =Dislike slightly, $3=$ Dislike moderately, $2=$ Dislike very much and 1 = Dislike extremely. The results were evaluated by Analysis of Variance and Duncan Multiple Range Test (DMRT).

\section{Results and Discussion}

\section{Physical appearance of extracted and unextracted chickpea husk}

It has been observed that the extracted chickpea husk had darker brown color while unextracted chickpea husk had light brown color. The darker color may be due to heating process of extracted husk during drying. According to Chakraverty (1998), seed coat color of chickpea may be brown, yellow, and black, sometimes with black spots.

\section{Composition of extracted and unextracted chickpea husk}

These extracted and unextracted chickpea husk were analyzed for their moisture, ash, protein, fat, crude fiber and total carbohydrate contents. The results are presented in Table 3.

Table 3. Composition of extracted and unextracted chickpea husk

\begin{tabular}{|l|c|c|}
\hline Components & Extracted chickpea husk & Unextracted chickpea husk \\
\hline Moisture (\%) & 5.84 & 14.25 \\
\hline Ash (\%) & 3.23 & 3.95 \\
\hline Protein (\%) & 4.35 & 5.03 \\
\hline Fat (\%) & 0.56 & 0.70 \\
\hline Crude fiber (\%) & 43.67 & 34.50 \\
\hline Total carbohydrate (by difference) (\%) & 86.02 & 76.07 \\
\hline
\end{tabular}

\section{Effect of various levels of extracted and unextracted chickpea husk on the quality of chapatti}

Chapattis were made by incorporation of extracted and unextracted chickpea husk at $0-12 \%$ substitution levels in the formulations and the chapattis were evaluated for their weight, width, thickness, spread ratio and moisture content. The results are presented in the Table 4.

With different levels of chickpea husk addition from 0-12\%, the extracted husk yielded chapatti with lower weights than unextracted husk. This variation in chapatti weight may result from the increased water absorption by the unextracted husk. Chapatti made with unextracted husk absorbed more water because unextracted husk did not go through the dryer as that of extracted husk. The dough containing the extracted husk samples absorbed less water than the unextracted husk at the same substitution level. It is also seen that the weights of all the chapatti samples (Table 4) are higher than that of control (without husk) chapatti.

Within a substitute level of $0-12 \%$, the extracted husk in general produced chapatti has higher width than unextracted husk. The extracted and unextracted husk yielded chapatti with more or less similar thickness at $0-12 \%$ substitution level. But it is seen that the width of chapatti decreased gradually with increasing level of the extracted and unextracted chickpea husk. 
The spread ratio of chapatti decreased progressively with increasing the different level of chickpea husk both extracted and unextracted. The control chapatti has the highest spread ratio. In general, the extracted husk yielded chapatti with higher spread ratio than those of unextracted husk at the similar substitution level. This indicated that the finer husk particles had beneficial effects on the spreading of chapatti.

The chapatti with extracted husk had lower moisture contents than those with unextracted husk incorporated at the same substitution level. The increasing levels of husk from $0-12 \%$, the moisture content of chapatti increased progressively for both extracted and unextracted husk. Here moisture content was determined by wet basis. However, the particle size of the husk affected the moisture content of chapatti. The larger husk particles of unextracted husk absorbed more moisture content than the smaller husk particles of extracted husk which was used in chapatti formulations.

Table 4. Effect of various levels of extracted and unextracted chickpea husk on the weight, width, thickness, spread ratio and moisture content of chapatti

\begin{tabular}{|l|c|c|c|c|c|c|}
\hline Chapatti type & $\begin{array}{c}\text { Substitution levels } \\
\text { for chickpea husk } \\
(\%)\end{array}$ & $\begin{array}{c}\text { Weight } \\
(\mathrm{g})\end{array}$ & $\begin{array}{c}\text { Width } \\
(\mathrm{W}) \\
\text { in } \mathrm{cm}\end{array}$ & $\begin{array}{c}\text { Thickness } \\
(\mathrm{T}) \\
\text { in } \mathrm{cm}\end{array}$ & $\begin{array}{c}\text { Spread } \\
\text { Ratio } \\
(\mathrm{W} / \mathrm{T})\end{array}$ & $\begin{array}{c}\text { Moisture } \\
\text { Content } \\
(\%)\end{array}$ \\
\hline Control & 0 & 16.70 & 10.0 & 0.250 & 40.00 & 27.70 \\
\hline \multirow{4}{*}{ Extracted husk } & 2 & 18.40 & 9.80 & 0.252 & 38.88 & 28.88 \\
\cline { 2 - 7 } & 5 & 18.85 & 9.77 & 0.254 & 38.46 & 29.48 \\
\cline { 2 - 7 } & 7 & 19.50 & 9.75 & 0.255 & 38.23 & 29.56 \\
\cline { 2 - 7 } & 10 & 20.40 & 9.71 & 0.257 & 37.78 & 29.69 \\
\hline \multirow{3}{*}{$\begin{array}{l}\text { Unextracted } \\
\text { husk }\end{array}$} & 21.20 & 9.65 & 0.258 & 37.40 & 30.05 \\
\cline { 2 - 7 } & 2 & 19.30 & 9.69 & 0.253 & 38.30 & 29.10 \\
\cline { 2 - 7 } & 5 & 20.45 & 9.64 & 0.255 & 37.80 & 29.35 \\
\cline { 2 - 7 } & 7 & 21.20 & 9.61 & 0.256 & 37.54 & 29.47 \\
\cline { 2 - 7 } & 10 & 22.35 & 9.57 & 0.258 & 37.09 & 29.87 \\
\hline
\end{tabular}

\section{Effects of extracted and unextracted chickpea husk on the composition of chapatti}

Chapattis prepared by incorporating $5 \%$ extracted and unextracted chickpea husk were evaluated for moisture content, protein, ash, crude fiber and carbohydrate content. The results were presented in Table 5 . With the addition of $5 \%$ chickpea husk (both extracted and unextracted), the level of moisture, ash and crude fiber content increased while protein and carbohydrate content decreased when compared with the control chapatti. The composition of extracted and unextracted chickpea husk under this study was more or less similar to those found by Monirul Islam (2000). Moisture content of chapatti containing extracted husk was slightly lower because extracted husk went through drying process. Protein content was also lower of those chapattis than those made with unextracted husk because unextracted husk contained some broken parts of chickpea. Crude fiber content of chapatti containing extracted husk was slightly higher because extracted husk always contains more crude fiber than unextracted husk.

Table 5. Composition of chapatti containing extracted and unextracted chickpea husk

\begin{tabular}{|l|c|c|c|}
\hline \multirow{2}{*}{ Components } & Control chapatti & \multicolumn{2}{c|}{ Chapatti containing husk } \\
\cline { 3 - 4 } & (without husk) & $5 \%$ extracted husk & $5 \%$ unextracted husk \\
\hline Moisture (\%) & 27.70 & 29.35 & 29.48 \\
\hline Protein (\%) & 9.64 & 7.88 & 8.40 \\
\hline Ash (\%) & 0.98 & 1.73 & 1.78 \\
\hline Crude fiber (\%) & 0.45 & 1.2 & 1.15 \\
\hline Total Carbohydrate (\%) (by difference) & 61.68 & 60.91 & 60.47 \\
\hline
\end{tabular}

\section{Effects of various levels of salt on the quality of chapatti}

The extracted and unextracted chickpea husk was mixed into a standard chickpea husk at 5\% substitution levels in the chapatti formulation. Here salt was added at the rate of $1-3 \%$ on the flour-husk weight basis. The physical properties were evaluated and the results are presented in Table 6 and Table 7. 
In case of width, it is observed from the Table 6 that the highest width of chapatti was achieved at 2\% level of salt addition and after increasing the percentage of salt, the width of all the chapattis gradually decreased. In case of thickness, it was observed that with different levels of salt addition from 1 to $3 \%$ the spread ratio increased fairly up to $2.0 \%$ and spread ratio of the chapatti decreased with $2.5 \%$ salt addition or above. The extracted chickpea husk yielded chapatti with higher spread ratio than those of chapatti with unextracted chickpea husk at the similar addition of salt. This indicated that the finer husk particles have beneficial effects on spreading of chapatti. Bose (2008) reported that similar effects were observed in sweet biscuits containing chickpea husk.

Table 6. Effects of various levels of salt on chapatti containing extracted and unextracted chickpea husk on the flour-husk weight basis

\begin{tabular}{|c|c|c|c|c|c|c|c|c|c|}
\hline \multirow{2}{*}{\begin{tabular}{c} 
Level of $\begin{array}{c}\text { salt addition } \\
(\%)\end{array}$ \\
\cline { 2 - 11 }
\end{tabular}} & \multicolumn{4}{|c|}{ Without husk (Control) } & \multicolumn{3}{c|}{ Chapatti supplement } \\
\cline { 2 - 10 } & $\begin{array}{c}\text { Width } \\
(\mathrm{W}) \mathrm{cm}\end{array}$ & $\begin{array}{c}\text { Thickness } \\
(\mathrm{T}) \\
\mathrm{cm}\end{array}$ & $\begin{array}{c}\text { Spread } \\
\text { ratio } \\
(\mathrm{W} / \mathrm{T})\end{array}$ & $\begin{array}{c}\text { Width } \\
(\mathrm{W}) \\
\mathrm{cm}\end{array}$ & $\begin{array}{c}\text { Thickness } \\
(\mathrm{T}) \\
\mathrm{cm}\end{array}$ & $\begin{array}{c}\text { Spread } \\
\text { ratio } \\
(\mathrm{W} / \mathrm{T})\end{array}$ & $\begin{array}{c}\text { Width } \\
(\mathrm{W}) \\
\mathrm{cm}\end{array}$ & $\begin{array}{c}\text { Thickness } \\
(\mathrm{T})\end{array}$ & $\begin{array}{c}\text { Spread } \\
\text { ratio } \\
(\mathrm{W} / \mathrm{T})\end{array}$ \\
\hline 1.0 & 9.70 & 0.250 & 38.80 & 9.60 & 0.251 & 38.25 & 9.54 & 0.252 & 37.86 \\
\hline 1.5 & 9.88 & 0.252 & 39.21 & 9.71 & 0.253 & 38.38 & 9.59 & 0.253 & 37.91 \\
\hline 2.0 & 10.00 & 0.254 & 40.00 & 9.77 & 0.254 & 38.46 & 9.64 & 0.255 & 37.80 \\
\hline 2.5 & 9.82 & 0.255 & 38.51 & 9.70 & 0.256 & 37.89 & 9.65 & 0.257 & 37.54 \\
\hline 3.0 & 9.68 & 0.257 & 37.67 & 9.66 & 0.258 & 37.44 & 9.55 & 0.258 & 37.01 \\
\hline
\end{tabular}

Table 7. Effects of various levels of salt on chapatti containing extracted and unextracted chickpea husk on the flour-husk weight basis

\begin{tabular}{|c|c|c|c|c|c|c|}
\hline \multirow{3}{*}{$\begin{array}{l}\text { Level of } \\
\text { salt addition } \\
\text { (\%) }\end{array}$} & \multicolumn{6}{|c|}{ Chapatti supplement } \\
\hline & \multicolumn{2}{|c|}{ Without husk (Control) } & \multicolumn{2}{|c|}{ 5\% Extracted husk } & \multicolumn{2}{|c|}{ 5\% Unextracted husk } \\
\hline & $\begin{array}{l}\text { Weight } \\
\text { (g) }\end{array}$ & $\begin{array}{c}\text { Moisture } \\
\text { Content (\%) }\end{array}$ & $\begin{array}{l}\text { Weight } \\
(\mathrm{g})\end{array}$ & $\begin{array}{c}\text { Moisture } \\
\text { Content (\%) }\end{array}$ & $\begin{array}{l}\text { Weight } \\
\text { (g) }\end{array}$ & $\begin{array}{c}\text { Moisture } \\
\text { Content (\%) }\end{array}$ \\
\hline 1.0 & 14.25 & 26.55 & 16.56 & 28.06 & 18.80 & 28.56 \\
\hline 1.5 & 15.50 & 27.26 & 17.78 & 28.74 & 19.15 & 29.10 \\
\hline 2.0 & 16.70 & 27.70 & 18.85 & 29.48 & 20.45 & 29.35 \\
\hline 2.5 & 15.56 & 27.56 & 18.03 & 29.01 & 19.24 & 28.89 \\
\hline 3.0 & 15.05 & 26.88 & 17.10 & 28.35 & 18.10 & 28.23 \\
\hline
\end{tabular}

The weight of the chapattis containing extracted and unextracted husk increased sharply up to $2 \%$ and thereafter the weight of the chapattis progressively decreased in all the cases. It can be found that the control chapattis has the lower weight than that of the chapattis made from extracted and unextracted husk. This variation in chapatti weight may result from the increased water absorption by the unextracted chickpea husk.

In the case of moisture content it was seen that the increasing level of salt affected the moisture content of the chapattis. The moisture of the chapattis using extracted or unextracted husk, progressively increased up to $2 \%$ level and there after the moisture content decreased slowly. The particle size of the husk affected the moisture content of the chapattis. The larger husk particle absorbed more moisture than the smaller husk particles.

\section{Effect of various levels of baking powder on the quality of chapatti}

The extracted chickpea husk was mixed into standard wheat flour at $5 \%$ substitution level in the formulation of chapattis. Baking powder was added at the rate of $0.5-2.5 \%$ on the dough weight basis. The physical properties of the chapattis were evaluated and the results are shown in Table 8 and Table 9. The width of the chapatti is significantly affected with the increasing levels of baking powder (Table 8). With the increasing levels of baking powder from 0.5 to $2.5 \%$ the width of the chapattis containing extracted or unextracted husk increased fairly up to $1.5 \%$ and $2.0 \%$ levels of baking powder addition and thereafter the width of the chapattis decreased. And it is also observed that with the increasing of the amount of baking powder, the thickness of chapattis (control chapatti, extracted husk or unextracted husk produced chapatti increased. The control chapatti had the highest spread ratio. In general, the extracted husk yielded chapatti with higher spread ratio than those of chapatti with unextracted husk at the similar substitution level. This indicates that the finer husk particles had beneficial effects on chapatti spread. 
The weight of the chapattis prepared from various levels of baking powder added with $5 \%$ extracted husk were comparatively lower than those of $5 \%$ unextracted husk (Table 9). This variation in chapatti weight may result from the increased water absorption by the unextracted chickpea husk. In the case of moisture content it is seen that the increasing level of baking powder affected the moisture content of the chapattis. The moisture of the chapattis using extracted or unextracted husk, progressively increased up to $1.5 \%$ and $2 \%$ (baking powder) level and there after the moisture content decreased slowly. It has been observed that $1 \%$ level of baking powder is more suitable for chapattis using $5 \%$ extracted and unextracted husk.

Table 8. Effects of various levels of baking powder on chapatti containing extracted and unextracted chickpea husk on the flour-husk weight basis

\begin{tabular}{|c|c|c|c|c|c|c|c|c|c|}
\hline \multirow{3}{*}{$\begin{array}{l}\text { Level of } \\
\text { baking powder } \\
\text { addition } \\
(\%)\end{array}$} & \multicolumn{9}{|c|}{ Chapatti supplement } \\
\hline & \multicolumn{3}{|c|}{ Without husk(Control) } & \multicolumn{3}{|c|}{ 5\% Extracted husk } & \multicolumn{3}{|c|}{ 5\% Unextracted husk } \\
\hline & $\begin{array}{l}\text { Width } \\
(\mathrm{W}) \\
\mathrm{cm}\end{array}$ & $\begin{array}{c}\text { Thickness } \\
(\mathrm{T}) \\
\mathrm{cm}\end{array}$ & $\begin{array}{c}\text { Spread } \\
\text { ratio } \\
(\mathrm{W} / \mathrm{T})\end{array}$ & $\begin{array}{l}\text { Width } \\
\text { (W) } \\
\mathrm{cm}\end{array}$ & $\begin{array}{c}\text { Thickness } \\
(\mathrm{T}) \\
\mathrm{cm}\end{array}$ & $\begin{array}{l}\text { Spread } \\
\text { ratio } \\
(\mathrm{W} / \mathrm{T})\end{array}$ & $\begin{array}{l}\text { Width } \\
\text { (W) } \\
\mathrm{cm}\end{array}$ & $\begin{array}{c}\text { Thickness } \\
(\mathrm{T}) \\
\mathrm{cm}\end{array}$ & $\begin{array}{c}\text { Spread } \\
\text { ratio } \\
(\mathrm{W} / \mathrm{T})\end{array}$ \\
\hline 0.5 & 9.94 & 0.249 & 39.92 & 9.68 & 0.252 & 38.41 & 9.56 & 0.253 & 37.78 \\
\hline 1.0 & 10.00 & 0.250 & 40.00 & 9.77 & 0.254 & 38.46 & 9.64 & 0.255 & 37.80 \\
\hline 1.5 & 10.32 & 0.254 & 40.63 & 9.85 & 0.255 & 38.62 & 9.77 & 0.256 & 38.16 \\
\hline 2.0 & 10.20 & 0.256 & 39.84 & 9.92 & 0.257 & 38.60 & 9.62 & 0.258 & 37.29 \\
\hline 2.5 & 10.15 & 0.259 & 39.49 & 9.82 & 0.258 & 38.06 & 9.57 & 0.259 & 36.95 \\
\hline
\end{tabular}

Table 9. Effects of various levels of baking powder on chapatti containing extracted and unextracted chickpea husk on the flour-husk weight basis

\begin{tabular}{|c|c|c|c|c|c|c|}
\hline \multirow{3}{*}{$\begin{array}{l}\text { Level of } \\
\text { baking powder } \\
\text { addition (\%) }\end{array}$} & \multicolumn{6}{|c|}{ Chapatti supplement } \\
\hline & \multicolumn{2}{|c|}{ Without husk (Control) } & \multicolumn{2}{|c|}{ 5\% Extracted husk } & \multicolumn{2}{|c|}{ 5\% Unextracted husk } \\
\hline & $\begin{array}{l}\text { Weight } \\
\text { (g) }\end{array}$ & $\begin{array}{c}\text { Moisture } \\
\text { Content (\%) }\end{array}$ & $\begin{array}{l}\text { Weight } \\
\text { (g) }\end{array}$ & $\begin{array}{c}\text { Moisture } \\
\text { Content (\%) }\end{array}$ & $\begin{array}{l}\text { Weight } \\
\text { (g) }\end{array}$ & $\begin{array}{c}\text { Moisture } \\
\text { Content (\%) }\end{array}$ \\
\hline 0.5 & 16.32 & 27.47 & 18.46 & 28.92 & 20.28 & 28.80 \\
\hline 1.0 & 16.70 & 27.70 & 18.85 & 29.48 & 20.45 & 29.35 \\
\hline 1.5 & 17.45 & 28.24 & 19.37 & 29.24 & 21.14 & 29.63 \\
\hline 2.0 & 17.22 & 27.96 & 18.64 & 28.88 & 21.56 & 29.96 \\
\hline 2.5 & 16.80 & 27.67 & 18.32 & 28.71 & 21.19 & 29.56 \\
\hline
\end{tabular}

\section{Effect of various levels of water on the quality of chapatti}

At $5 \%$ substitution levels, the extracted and unextracted chickpea husk were mixed in the chapatti formulation and water was added at the rate of $56-66 \%$ on the flour-husk weight basis. The physical properties of chapatti were evaluated and the results are presented in Table 10 and Table 11.

The width of the chapatti is significantly affected with the increasing levels of water (Table 10). It is observed that highest width of chapattis was achieved at $60 \%$ and $62 \%$ levels of water addition and after attaining the maximum value, the chapatti width progressively decreased in all the cases. And it is also observed that with the increasing of the amount of water, the thickness of control chapatti and chapatti with extracted or unextracted husk increased. The control chapatti had the highest spread ratio. In general, the extracted husk yielded chapatti with higher spread ratio than those of chapatti with unextracted husk at the similar substitution level. This indicates that the finer husk particles had beneficial effects on chapatti spread.

The weight of the chapattis containing extracted and unextracted husk increased sharply up to $60 \%$ and $62 \%$ levels and thereafter the weight of the chapattis progressively decreased in all the cases. The weight of the chapattis prepared from various levels of water added with 5\% extracted husk was comparatively lower than those of $5 \%$ unextracted husk (Table 11). This variation in chapatti weight may result from the increased water absorption by the unextracted chickpea husk. The moisture of the chapattis using extracted or unextracted husk, progressively increased up to $60 \%$ and $62 \%$ level and there after the moisture content decreased slowly. The larger husk particle absorbed more moisture than the smaller husk particles. It has been observed that $62 \%$ level of water is more suitable for chapattis using $5 \%$ extracted husk. 
Table 10. Effects of various levels of water on chapatti containing extracted and unextracted chickpea husk on the flour-husk weight basis

\begin{tabular}{|c|c|c|c|c|c|c|c|c|c|}
\hline \multirow{3}{*}{$\begin{array}{l}\text { Level of } \\
\text { water } \\
\text { addition } \\
(\%)\end{array}$} & \multicolumn{9}{|c|}{ Chapatti supplement } \\
\hline & \multicolumn{3}{|c|}{ Without husk (Control) } & \multicolumn{3}{|c|}{$5 \%$ Extracted husk } & \multicolumn{3}{|c|}{ 5\% Unextracted husk } \\
\hline & $\begin{array}{l}\text { Width } \\
\text { (W) } \\
\mathrm{cm}\end{array}$ & $\begin{array}{c}\text { Thickness } \\
(\mathrm{T}) \\
\mathrm{cm}\end{array}$ & $\begin{array}{l}\text { Spread } \\
\text { ratio } \\
(\mathrm{W} / \mathrm{T})\end{array}$ & $\begin{array}{l}\text { Width } \\
(\mathrm{W}) \\
\mathrm{cm}\end{array}$ & $\begin{array}{c}\text { Thickness } \\
(\mathrm{T}) \\
\mathrm{cm}\end{array}$ & $\begin{array}{c}\text { Spread } \\
\text { ratio } \\
(\mathrm{W} / \mathrm{T})\end{array}$ & $\begin{array}{l}\text { Width } \\
(\mathrm{W}) \\
\mathrm{cm}\end{array}$ & $\begin{array}{c}\text { Thickness } \\
(\mathrm{T}) \\
\mathrm{cm}\end{array}$ & $\begin{array}{c}\text { Spread } \\
\text { ratio } \\
(\mathrm{W} / \mathrm{T})\end{array}$ \\
\hline 56 & 9.45 & 0.250 & 37.80 & 9.28 & 0.251 & 36.97 & 9.27 & 0.252 & 36.78 \\
\hline 58 & 9.67 & 0.252 & 38.37 & 9.56 & 0.253 & 37.78 & 9.49 & 0.254 & 37.36 \\
\hline 60 & 10.00 & 0.254 & 40.00 & 9.77 & 0.254 & 38.26 & 9.64 & 0.255 & 37.80 \\
\hline 62 & 10.24 & 0.255 & 40.16 & 9.80 & 0.256 & 38.28 & 9.63 & 0.257 & 37.47 \\
\hline 64 & 10.06 & 0.257 & 39.14 & 9.47 & 0.258 & 36.70 & 9.62 & 0.258 & 37.28 \\
\hline 66 & 9.89 & 0.258 & 38.33 & 9.30 & 0.259 & 35.91 & 9.36 & 0.260 & 36.00 \\
\hline
\end{tabular}

Table 11. Effects of various levels of water on chapatti containing extracted and unextracted chickpea husk on the flour-husk weight basis

\begin{tabular}{|c|c|c|c|c|c|c|}
\hline \multirow{2}{*}{$\begin{array}{l}\text { Level of water } \\
\text { addition } \\
(\%)\end{array}$} & \multicolumn{4}{|c|}{ Chapatti supplement } \\
\cline { 2 - 7 } & \multicolumn{2}{|c|}{ Without husk (Control) } & \multicolumn{2}{c|}{$5 \%$ Extracted husk } & \multicolumn{2}{c|}{$5 \%$ Unextracted husk } \\
\cline { 2 - 7 } & $\begin{array}{c}\text { Weight } \\
(\mathrm{g})\end{array}$ & $\begin{array}{c}\text { Moisture } \\
\text { Content (\%) }\end{array}$ & $\begin{array}{c}\text { Weight } \\
(\mathrm{g})\end{array}$ & $\begin{array}{c}\text { Moisture } \\
\text { Content }(\%)\end{array}$ & $\begin{array}{c}\text { Weight } \\
(\mathrm{g})\end{array}$ & $\begin{array}{c}\text { Moisture } \\
\text { Content }(\%)\end{array}$ \\
\hline 56 & 15.85 & 26.94 & 17.27 & 28.66 & 29.56 & 28.88 \\
\hline 58 & 16.25 & 27.37 & 18.39 & 29.04 & 20.27 & 29.20 \\
\hline 60 & 16.70 & 27.70 & 18.42 & 29.22 & 20.71 & 29.83 \\
\hline 62 & 16.94 & 27.97 & 18.85 & 29.48 & 20.45 & 29.35 \\
\hline 64 & 16.66 & 27.62 & 18.19 & 29.07 & 20.34 & 29.33 \\
\hline 66 & 16.29 & 27.33 & 17.83 & 28.79 & 19.91 & 28.75 \\
\hline
\end{tabular}

\section{Sensory evaluation of the chapatti containing extracted and unextracted chickpea husk}

Chapatti containing 5\% extracted and unextracted chickpea husk was subjected to sensory evaluation by a panel of 16 testers. The mean scores for preference of color, flavor, texture and overall acceptability of the chapattis were presented in Table 12. A two way analysis of variance indicated that all these sensory attributes of different chapattis were significantly $(p<0.01)$ different and thus the sensory attribute of all the chapatti samples showed varied degrees of acceptability. There was significantly difference in color preference between the chapatti containing extracted husk, unextracted husk and the control sample as shown in Table 12. The Duncan's Multiple Test (DMRT) revealed that the control chapatti scored highest for color followed by chapatti containing extracted and unextracted chickpea husk respectively. However, the color of the chapatti containing extracted chickpea husk was significantly better than that containing unextracted chickpea husk. The flavor of the chapatti containing extracted husk was significantly better than that containing unextracted husk. The texture of the chapatti containing extracted husk was significantly better than that containing unextracted husk. However, the overall acceptability of the chapatti containing extracted husk was significantly better than that containing unextracted husk. Among the experimental chapattis, the highest overall acceptability was achieved with $5 \%$ extracted chickpea husk substituted chapatti followed by $5 \%$ unextracted chickpea husk substituted chapatti.

Table 12. Mean sensory score of chapattis containing extracted and unextracted chickpea husk

\begin{tabular}{|l|c|c|c|c|}
\hline \multirow{2}{*}{\multicolumn{1}{|c|}{ Chapatti type }} & \multicolumn{4}{c|}{ Sensory attributes } \\
\cline { 2 - 5 } & Color & Flavor & Texture & Overall acceptability \\
\hline Control (wheat flour only) & $8.063^{\mathrm{a}}$ & $7.625^{\mathrm{a}}$ & $7.250^{\mathrm{a}}$ & $7.375^{\mathrm{a}}$ \\
\hline $5 \%$ extracted husk & $6.625^{\mathrm{b}}$ & $6.625^{\mathrm{b}}$ & $6.813^{\mathrm{ab}}$ & $6.750^{\mathrm{b}}$ \\
\hline $5 \%$ unextracted husk & $6.438^{\mathrm{b}}$ & $6.000^{\mathrm{c}}$ & $6.438^{\mathrm{b}}$ & $6.188^{\mathrm{c}}$ \\
\hline L.S.D $(\mathrm{P}<0.05)$ & 0.5901 & 0.5247 & 0.5803 & 0.3417 \\
\hline
\end{tabular}

\section{Summary and Conclusion}

Chickpea husks were extracted by non-alkaline aqueous extraction process and then ground in flour mill. The unextracted husks were also ground in flour mill. The extracted ground chickpea husk (processed husk) contained $5.84 \%$ moisture, $3.23 \%$ ash, $4.35 \%$ protein, $0.56 \%$ fat, $43.67 \%$ crude fiber, $86.02 \%$ carbohydrate and the unextracted chickpea husk showed $14.25 \%$ moisture, $3.95 \%$ ash, $5.03 \%$ protein, $0.70 \%$ fat, $34.50 \%$ crude fiber, $76.07 \%$ carbohydrate. 
Chapattis were prepared incorporating different levels of extracted and unextracted chickpea husk in the formulation and evaluated for various quality parameters as weight, width, thickness, spread ratio, and moisture content. In general the spread ratio of chapattis resulted from the replacement of wheat flour with extracted chickpea husk was found to be quite lower than that of the control chapattis. Moisture contents of chapattis supplemented with processed extracted and unextracted husks were higher than that of control (without husk) chapatti.

The increasing level of extracted and unextracted chickpea husk from $0-12 \%$ in the formulation increased the weight and moisture content of chapattis. The control chapatti and chapatti containing $5 \%$ extracted or unextracted chickpea husk were evaluated for the organoleptic properties. The total scores for preference of color, flavor, texture and overall acceptability were found higher for the control chapatti than those of chapattis incorporated with $5 \%$ extracted husk or unextracted husk. Chapattis containing 5\% extracted and unextracted husk were analyzed for their composition. The control chapatti contained $27.70 \%$ moisture content, $9.64 \%$ protein, $0.98 \%$ ash, $0.45 \%$ crude fiber and $61.68 \%$ carbohydrate. The composition of chapatti containing $5 \%$ extracted husk showed $29.48 \%$ moisture, $1.73 \%$ ash, $7.88 \%$ protein, $1.2 \%$ crude fiber and $60.91 \%$ carbohydrate. On the other hand, the composition of chapatti containing $5 \%$ unextracted husk showed $29.35 \%$ moisture, $1.78 \%$ ash, $8.40 \%$ protein, $1.15 \%$ crude fiber and $60.47 \%$ carbohydrate. It is evident that the incorporation of extracted chickpea husk in chapatti formulation has significantly increased the crude fiber content of the chapatti indicating higher level of dietary fiber when compared with conventional chapatti prepared without chickpea husk.

It was observed that chapatti containing $5 \%$ extracted husk required $2.0 \%$ salt, $1.5 \%$ baking powder and $62 \%$ water for producing reasonably acceptable quality of chapatti. In case of that chapatti containing $5 \%$ unextracted husk $1.5 \%$ salt, $1.5 \%$ baking powder and $60 \%$ water was optimum for achieving better quality of chapatti.

Statistical analysis for sensory evaluation data of both chapattis containing extracted or unextracted husk showed that control chapatti (without husk) secured the highest score for color, flavor, texture and overall acceptability. However, chapattis containing 5\% extracted husk secured higher score than those with unextracted husk. Further study may include detail investigation on the nutritional constituents and shelf stability of the chapatti containing processed chickpea husk.

\section{References}

AOAC. 1995. Official Methods of Analysis of the Association of official analytical chemists. Washington, DC.

AOAC. 2000. Official Methods of Analysis of the Association of Official Analytical Chemists. $15^{\text {th }}$ Edition. Washington, DC.

BBS. 2007. Year Book of Agricultural Statistics of Bangladesh, Ministry of Planning, Gov. of the People's Republic of Bangladesh, Dhaka.

Bose, D. 2008. Processing and utilization of chickpea husk to manufacture high fiber biscuits. MS thesis. Dept. Food Tech. and Rural Ind., Bangladesh Agricultural Univ. Mymensingh.

Burkitt, D.P. 1980. Don't forget fibre in your diet, $4^{\text {th }}$ Ed. Collins Publ. Co. Sydney. p. 76.

Burkitt, D.P. and Trowell, H. C. 1975. Refined carbohydrate foods and diseases, Academic Press London. pp 67-69.

Chakraverty, A. 1998. Postharvest Technology of Cereals, Pulses and Oilseeds, Oxford and IBH Pub. Co., New Delhi, India.

Chavan, J.K. and Duggal, S.K. 1978. Synergistic effect of different pulses on the protein quality of rice. J. Sci. Food Agric., 29: $230-236$.

Islam, M. 2000. The Effects of aqueous extracted rice bran on the baking quality of roti. MS thesis, Dept. Food Tech. and Rural Ind., Bangladesh Agricultural Univ. Mymensingh.

Roberts, P.J., Simmonds, D.H. and Wooton, M. 1985. Extraction of protein and solids from wheat bran. J. Sci. Food Agr. 36: 5-10.

Salunkhe, D.K., Kadam, S.S. and Chavan, J.K. 1985. Postharvest Biotechnology of Food Legumes, CRC press, Inc. Boca Raton, Florida.

Shams-Ud-Din, M., Chowhury, A.B. and Islam, M.M. 2006. Studies on the effects of processed pea Husk on bread quality, Bangladesh J. Agril. Engg. 17(1\&2): 73-82.

Singh, U. and Jambunathan, R. 1982. Distribution of seed protein fractions and amino acids in different anatomical pares of chickpea and pigeon pea, Qual. Plant, Plant Foods Hum. Nutr., 31, 347.

Southgate, D.A.T. and Penson, J.M. 1985 In: Dietary fibre, Eds. Birch, G.G. and parker, K.J. Applied Science publishers, London and New York, 1-20.

Spillers, G.A. Shipley, E.A. and Blake, J.A. 1978. Recent progress in dietary fibre (plantrix) in human nutrition. CRC Critical Rev. Food Sci. Nutr. 10: 31-46. 